\title{
DOES JEWISH PHILANTHROPY DIFFER BY SEX AND TYPE OF GIVING?
}

\author{
Debra Mesch, Zach Moore and Mark Ottoni-Wilhelm
}

Little has been written on the role of gender in Jewish philanthropy, and there is even less empirical research on gender differences between Jewish men and women, or between Jews and non-Jews by gender. This study examines Jewish philanthropy by type of giving and gender. Specifically, we examine the differing amounts given to charity (both religious and secular) across eight groups, controlling for other factors that may affect philanthropic giving. These included four groups of married couples: those consisting of two Jewish spouses, of a Jewish man and a non-Jewish woman, of a non-Jewish man and a Jewish woman, and of two non-Jewish spouses; and four groups of singles: Jewish men, Jewish women, non-Jewish men and non-Jewish women. Using three waves of data from the Panel Study of Income Dynamics (PSID), we used regression methods to examine the differences among the groups. Results indicated that the probability of giving and the amount given among Jewish women married to non-Jewish men are significantly less than among all other groups.

Philanthropy is rooted and often reflected in the values and norms of the religious groups that compose our communities. As Gary Tobin has remarked, "What communities as a whole and the subgroups within them think and feel are often revealed through their patterns of giving."' The relationship between religion and philanthropic giving has been extensively deliberated in the sociological, historical and religious studies literature. Empirical research-primarily from the U.S.-shows a strong and positive relationship between religious involvement and giving, for both secular and religious giving. ${ }^{2}$ For the most part, these studies indicate that religious affiliation, church membership and/or frequency of church attendance appear to have an important impact on philanthropic behavior-even after controlling for human and other demographic characteristics.

Several cross-denominational studies have compared giving between Protestants and Catholics, ${ }^{3}$ but few have addressed giving by other religious groups. ${ }^{4}$ Although 
the Jewish population is small in size (approximately 13.3 million worldwide, over $40 \%$ of them in the United States), ${ }^{5}$ the Jewish religion enjoys a long and rich history of philanthropy. "As a community," say Tobin and A.K. Weinberg, "Jews give disproportionately more than their numbers would indicate and even more so when it comes to America's largest gifts." Specifically, American Jews provide $25 \%$ of the largest donations to higher education, and more than $90 \%$ of the gifts of $\$ 1$ million or more disbursed by Jewish donors and foundations go to a wide variety of non-Jewish charities. ${ }^{6}$

Several Jewish scholars have discussed the importance of tzedakah-charity; literally: "doing justly" - a Jewish religious obligation to provide for those in need. ${ }^{7}$ As J.I. Lifschitz puts it, "Jewish tradition insists that man can, and should, have a powerful impact upon the material world." ${ }^{8}$ Tobin characterizes Jewish philanthropy as being both a "reflector" of Jewish values, mirroring the values and character of the Jewish community at large, and a "determinant and molder" of those values. ${ }^{9}$ Accordingly, philanthropy is highly institutionalized in American Jewish life, ${ }^{10}$ and examples abound of Jewish foundations that are dedicated to "educating, leading, and defining the values of American Jewish society." Jewish identity has been found to be strongly associated with philanthropic behavior. ${ }^{11}$ Nevertheless, empirical research on Jewish giving is extremely limited. ${ }^{12}$

The purpose of this study is to take a closer look at giving within American Jewish households and to examine differences by sex between Jewish and non-Jewish giving to both secular and religious causes, controlling for other factors that may affect philanthropic giving. Although there is some research on how charitable giving is decided and managed within a household ${ }^{13}$ little inquiry has focused on gender differences across religious denominations. This study will compare household giving by gender, married versus single status, and Jewish versus non-Jewish households.

\section{Jewish Philanthropy}

The few comparative studies that have included Jewish giving have produced some noteworthy findings. I.E. Berger's study of philanthropic behavior by religion in Canada found Jews and conservative Protestants to be very similar in their reasons/ motives for giving. Members of both groups were highly motivated by their feelings of altruism and perceived social obligations; for both, their giving was determined by strongly held "positive personal attitudes coupled with strong norms of group obligation and reciprocity." Among Jews, in particular, "group norms support general communal giving, as opposed to religious giving . . .72\% of Jewish giving is directed toward non-religious causes . . . , making the Jewish group the highest givers in the non-religious domain." 14

Using the Panel Study of Income Dynamics, Mark Ottoni-Wilhelm examined differences across denominational identities in giving to help people in need. He found that Jewish families-even controlling for income, wealth, and other demographic 
factors -were more likely both to give and to give larger amounts in order to help people with basic needs for food, shelter or other basic necessities. ${ }^{15}$ These findings are consistent with Jewish beliefs and with the explicit biblical commandments to give charity to the poor and not to ignore their distress. Jewish theology, according to Lifschitz, gives the individual "both the power and the responsibility to fashion the world as he sees fit and thereby take care of himself and of those around him" by helping the weak and giving to the poor. ${ }^{16}$

The most comprehensive data collected in The National Jewish Population Survey 2000-01 support the importance of tzedakah among Jews, indicating that charitable and philanthropic giving are deep-rooted in Jewish life. Specifically, this report found that $62 \%$ of American Jews give to non-Jewish causes, and $41 \%$ donate to Jewish causes other than federations. ${ }^{17}$ Using data from the Survey, C. Kadushin and L. Kotler-Berkowitz examined how informal social networks and formal organizational memberships among American Jews are related to philanthropy, controlling for demographic characteristics as well as denomination. ${ }^{18}$ They found that formal Jewish organizational memberships considerably raised the odds of Jews giving to non-Jewish causes, though not as much as it influenced their giving to Jewish causes, while strong informal networks with other Jews actually had a detrimental effect on giving to non-Jewish causes. Using control variables constructed from the Survey, their study also found that sex had no significant effect on giving to non-Jewish causes or to the Jewish Federation system.

Jewish philanthropic behavior was found by the Survey to be closely linked to age, life cycle, region and income. Although gender differences were not specified in this report, Tobin discusses the increasing influence of Jewish women in philanthropy. He contends that Jewish women have gained significant assets through increased labor participation, living past or divorcing wealthy husbands, or inheritance, allowing them to be "major contributors and decision-makers" and to take on important leadership roles within the philanthropic community. ${ }^{19}$ Tress and Kosmin's analysis showed that Jewish women's giving in federations is substantial-33.5\% of the total gifts raised by united Jewish community campaigns. ${ }^{20}$ Moreover, recent empirical research supports the increasing role that women overall play in economic and philanthropic decisionmaking. ${ }^{21}$ Furthermore, according to a commentary on Jewish women's philanthropy written by Susan Weidman Schneider, "partnership is the model for most Jewish couples." 22 Jewish women make independent financial decisions and influence their husbands' giving decisions.

Women's philanthropy presents an extraordinary developing opportunity to the Jewish community and to the world. In the past 30 years, women have emerged on the philanthropic landscape as a visible and bold presence. They are changing the face of philanthropy and transforming society around the world. Today's reality is that women, strengthened by increasing economic power and education, are as likely as men to be philanthropists. As Jewish philanthropy changes from a focus on federations to a more individual, market-driven base dominated by individuals and family foundations, ${ }^{23}$ research examining gender differences will be ever more important. 


\section{Giving and Gender}

Most of the empirical research that examines the relationship between gender and giving reveals that females are more generous and donate more to charity than males. ${ }^{24}$ However, HoAndreoni and Vesterlund's germinal study demonstrated that the question "Who is more generous?" is complex. Their study found differences in the "demand curves for altruism," with men being more responsive to the price of giving. They concluded that men are more generous when it is cheap to give, while women are more generous when it is more expensive to give. ${ }^{25}$

Cox and Deck, by contrast, found that women's generosity is more income-elastic; they were more responsive than men to variations in the cost of giving ${ }^{26}$ and were more likely to be generous when the stakes were lower. Kamas, Preston and Baum found that, under anonymous conditions, women gave significantly more than men; that they were more likely than men to give all the money away and less likely to keep all of the money; and that pairs consisting of one man and one woman gave more than same-sex pairs, with pairs of men giving the least: "Men acting with men behave more selfishly than women-however, when paired with women, men are willing to give more." ${ }^{27}$ Mesch et al. and Rooney et al., using, respectively, a representative national sample and an Indiana sample, found that single women, married men and married women were significantly more likely to be donors than single men. ${ }^{28}$ Piper and Schnepf's study examining men's and women's giving patterns in Great Britain supports the findings of Mesch et al. and Rooney et al. Women were more likely to give to charity, and this finding held for singles as well as married couples, with controls for background characteristics. ${ }^{29}$

Very relevant to our study, Andreoni, Brown and Rischall found evidence that charitable giving by married couples who decide on it jointly resembles the giving of married couples in which the husband alone decides. That is, even when married couples decide jointly, "husbands seem to be getting more of what they want than wives do." 30 Replication of this study using a different data set produced similar results: whether the husband or the wife was the primary decision-maker on charitable contributions produced significant differences in household giving. ${ }^{31}$

However, virtually no research has been conducted on gender differences in philanthropic giving within or across religious denominations or on the role of gender in Jewish philanthropy, and we could find no empirical research comparing Jews and non-Jews by gender. Our study, based on data obtained from large-scale survey of philanthropic giving in the United States, is a first effort to redress this deficiency.

\section{Methodology and Analysis}

Our analysis uses three waves of data from the Panel Study of Income Dynamics (PSID), fielded by the University of Michigan's Institute for Survey Research. Started in 1968, the PSID is the largest ( $n=8,002$ households) and longest-running panel study 


\section{Debra Mesch, Zach Moore and Mark Ottoni-Wilhelm}

in the world, with a year-to-year retention rate of $96 \%$ or above. The study includes a nationally representative sample and an over-sample of low-income and minority households. The present analysis uses both samples and therefore also uses the sample weights in order to obtain results representative of the U.S. population.

Starting in 2001, the Center on Philanthropy at Indiana University developed and sponsored a philanthropy module within the PSID: the Center on Philanthropy Panel Study (COPPS). Respondents are asked about their giving and volunteering in various subsectors. In addition, starting in 2003, the Center developed and sponsored questions about religious attendance.

We split the PSID charitable giving data into secular and religious giving. Respondents (i.e., households) are asked the following about religious giving:

Did you make any donations specifically for religious purposes or spiritual development, for example to a church, synagogue, mosque, TV or radio ministry? Please do not include donations to schools, hospitals, and other charities run by religious organizations. I will be asking you about those donations next.

[If yes]. Altogether, what was the total dollar value of all donations you [and your family] made in [year] towards religious purposes?

A similar question was asked about giving to secular causes, listed as including the following categories: (1) combination of purposes, such as the United Way, the United Jewish Appeal, Catholic Charities or local community foundation; (2) health care or medical research; (3) education; (4) youth or family services; (5) arts, culture or ethnic awareness; (6) improve neighborhoods and communities; (7) environment; (8) international aid; and (9) other. If the household gave $\$ 25$ or less, the amount was set to zero in the data.

For the present study, we examine differences between men's and women's giving by breaking the sample down into eight household groups: married couples consisting of (1) two Jewish spouses, (2) a Jewish man and a non-Jewish woman, (3) a non-Jewish man and a Jewish woman, and (4) two non-Jewish spouses; and single households including (5) single Jewish men, (6) single Jewish women, (7) single non-Jewish men, (8) single non-Jewish women. The single households included individuals who were never married, divorced/separated, and widows/widowers. Our total sample (Jews and non-Jews) is 6,359 households, of which 149 had at least one Jewish member: 60 Jewish married couples, 57 intermarried couples and 32 Jewish singles. The relatively small size of the Jewish sample population, which accurately reflects the percentage of Jews in the U.S. population (around 2\%), should be borne in mind when interpreting the results. Even so, as we will see, the sample size is large enough to draw statistically significant distinctions between families in which Jewish women are married to non-Jewish men and other Jewish households.

In analyzing the results, we use regression methods to examine gender differences among households with Jewish members while controlling for differences in their observable characteristics, such as income, wealth, education, age, number of children, 
Table 1: Non-Jewish and Jewish Giving

\begin{tabular}{lcc|cc}
\hline & \multicolumn{2}{c|}{ Non-Jewish $\mathrm{n}=6210$} & \multicolumn{2}{c}{ At least one Jewish $\mathrm{n}=149$} \\
\hline & $\begin{array}{c}\text { Percent } \\
\text { who give }\end{array}$ & $\begin{array}{c}\text { Average amount } \\
\text { among givers }\end{array}$ & $\begin{array}{c}\text { Percent } \\
\text { who give }\end{array}$ & $\begin{array}{c}\text { Average amount } \\
\text { among givers }\end{array}$ \\
Religious Giving & 0.62 & 1440 & 0.69 & 2221 \\
Secular Giving & 0.76 & {$[506]$} & 0.96 & {$[548]$} \\
& & 660 & & 1967 \\
\hline
\end{tabular}

Note: The summary statistics are weighted to account for unequal selection probability and attrition in the study.

The amount in brackets is the median.

age of youngest child, region, employment status and health. The use of the PSID has several advantages. First, we can determine whether any gender differences among households with Jewish members are similar to those that exist among all households, or whether there are gender differences that are specific to Jews. Second, we can examine differences among households longitudinally across the same respondents/ household over three years (2000, 2002 and 2004), instead of the more usual singleyear cross-section, which runs the risk of missing respondents who gave in one year and not another. Third, the PSID data, both on giving and on important control variables such as income and wealth, are of high quality. Mark Wilhelm has argued that the quality of the COPPS data may be superior to that collected in other household surveys of charitable giving, because of the PSID staff's experience in data collection and the respondents' familiarity with the survey procedure. ${ }^{32}$

\section{Results}

Tables 1,2 and 3 report the descriptive statistics for the sample. Table 1 compares religious and secular giving (as defined by the study), without controls, in the non-Jewish households and those with a Jewish member. The data show that households with at least one Jewish individual were $11 \%$ more likely to give to religion (69\% as opposed to $62 \%)$ and gave an average of $54 \%$ more $(\$ 2,221$ as opposed to $\$ 1,440)$ than nonJewish households. For secular giving, the difference in the percentage of givers was significantly greater ( $96 \%$ as opposed to $76 \%$ ) - so that the households with at least one Jewish member were $26 \%$ more likely to give to secular causes and gave an average of three times more $(\$ 1,967$ as opposed to $\$ 660)$ than the non-Jewish households.

Table 2, which breaks down the sample of marrieds and singles into the eight abovementioned groups, again without controls, yields some noteworthy comparative data. First, for the couples, if one (either the man or the woman) or both members were Jewish, secular giving was higher compared to non-Jewish couples. Second, if both were Jewish, the likelihood and amount of religious giving was greater than for any of the other married couples. Third, comparing married couples in which both spouses 
Table 2: Descriptive Statistics of Sample by Marrieds and Singles

\begin{tabular}{lcccc|cccc}
\hline & \multicolumn{3}{c}{ Married/Couples } & \multicolumn{5}{c}{ Singles } \\
& $\begin{array}{l}\text { Both Non- } \\
\text { Jewish } \\
\mathrm{n}=3801\end{array}$ & $\begin{array}{c}\text { Man } \\
\text { Jewish } \\
\mathrm{n}=32\end{array}$ & $\begin{array}{c}\text { Woman } \\
\text { Jewish } \\
\mathrm{n}=25\end{array}$ & $\begin{array}{c}\text { Both } \\
\text { Jewish } \\
\mathrm{n}=60\end{array}$ & $\begin{array}{c}\text { Jewish } \\
\text { Man } \\
\mathrm{n}=675\end{array}$ & $\begin{array}{c}\text { Non- } \\
\text { Jewish } \\
\text { Woman } \\
\mathrm{n}=1734\end{array}$ & $\begin{array}{c}\text { Jewish } \\
\text { Man }\end{array}$ & $\begin{array}{c}\text { Jewish } \\
\text { Woman } \\
\mathrm{n}=20\end{array}$ \\
\hline $\begin{array}{l}\text { Religious Giving } \\
\begin{array}{l}\text { Percent who } \\
\text { give }\end{array}\end{array}$ & 0.68 & 0.55 & 0.67 & 0.85 & 0.47 & 0.57 & 0.53 & 0.56 \\
$\begin{array}{l}\text { Avg. amount } \\
\text { among givers }\end{array}$ & 1794 & 570 & 961 & 2020 & 753 & 881 & 12104 & 339 \\
$\begin{array}{l}\text { Median amount } \\
\text { among givers }\end{array}$ & 661 & 500 & 688 & 1019 & 347 & 388 & 333 & 160 \\
$\begin{array}{l}\text { Secular Giving } \\
\begin{array}{l}\text { Percent who } \\
\text { give }\end{array}\end{array}$ & 0.81 & 0.99 & 0.98 & 0.99 & 0.65 & 0.71 & 0.95 & 0.84 \\
$\begin{array}{l}\text { Avg. amount } \\
\text { among givers }\end{array}$ & 760 & 1943 & 1963 & 2227 & 550 & 483 & 2348 & 1039 \\
$\begin{array}{l}\text { Median amount } \\
\text { among givers }\end{array}$ & 326 & 868 & 485 & 1227 & 184 & 169 & 1008 & 469 \\
\hline
\end{tabular}

Note: The summary statistics are weighted.

were non-Jewish or both Jewish, we see that the Jewish couples gave significantly more and were more likely to give than the non-Jewish couples to both religious and secular causes. The Jewish singles, too, both men and women, were more likely to give and gave more to secular causes than the non-Jewish singles. The single Jewish men gave the most to both secular and religious causes (though we again caution by noting the very small sample size for this group, $n=12$ ), and their average amount of religious giving was especially high. We examined the reported amounts for the single Jewish men to confirm the accuracy of these data. ${ }^{33}$ However, the single Jewish women gave significantly less to religion than the non-Jewish singles, both men and women.

Table 3 reports the demographic characteristics of the sample: income, wealth, education, age, number of children and percentage of heads of households employed in the workforce. These data indicated that, in our sample, income and wealth were much greater among the couples with a Jewish female spouse married to a non-Jewish male than in the other comparison groups; education was highest for a single Jewish men and for couples whose members were both Jewish; and the mean age of the head of household was higher for the couples whose members were both Jewish and for the single Jewish women.

Table 4 reports a set of results that parallel those in Table 2, except that they are taken from a regression model that controls for: (a) income (in 2004), ${ }^{34}$ (b) average wealth (assets - with and without house), (c) education (categorical variable, less than 
Table 3: Descriptive Statistics of Sample by Marrieds and Singles with Descriptives of Control Variables Used

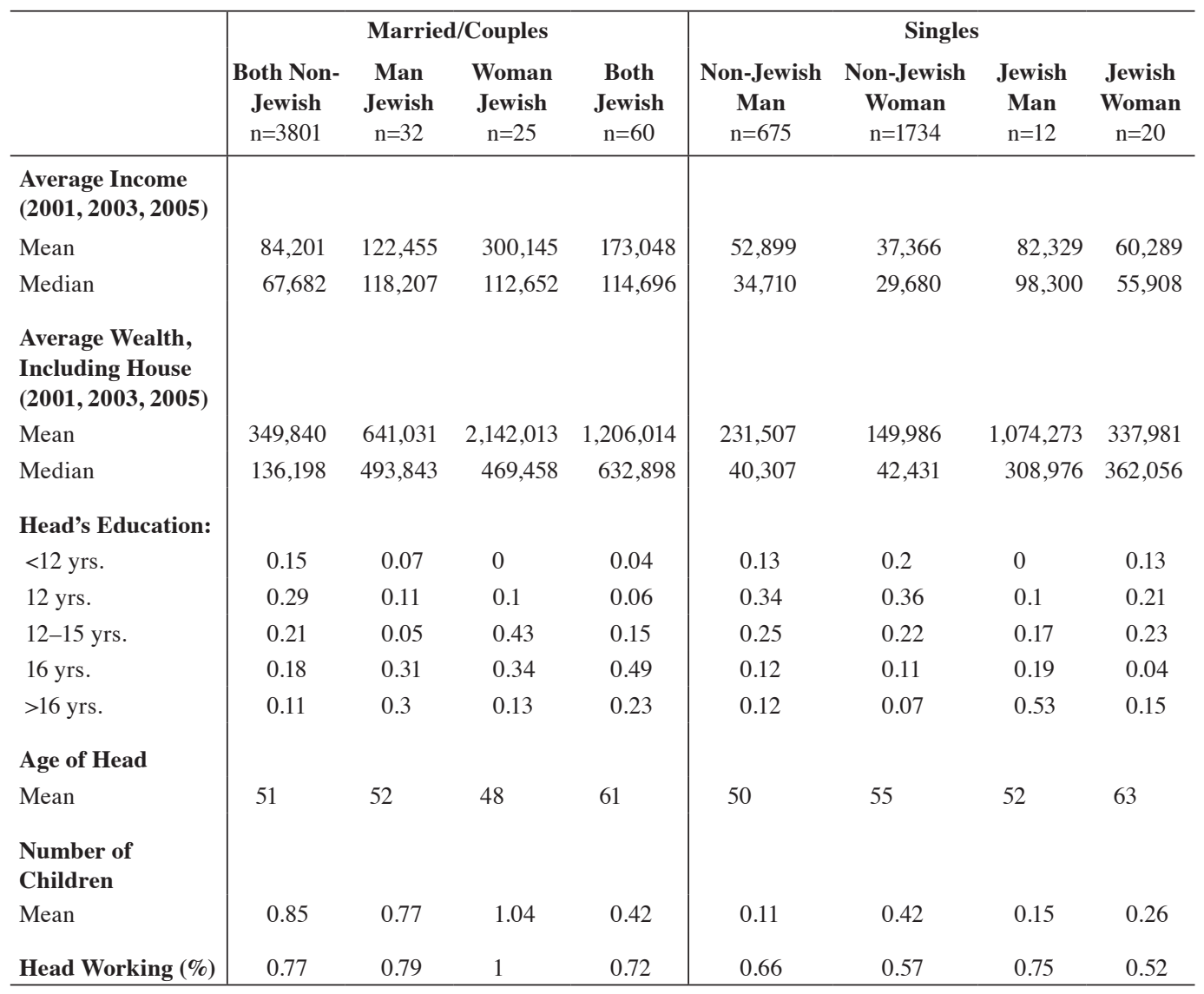

Note: The summary statistics are weighted.

high school through post-B.A.), (d) age, (e) number of children, (e) age of youngest child, (f) region (dummy variable of regions in U.S.), (g) employment status (working or not working) and (h) health (poor/fair/good). In the regressions, the omitted reference group was that of the intermarried couples consisting of a Jewish woman and a non-Jewish man.

For secular giving, the results in Table 4 indicated that the probability of giving for the couples in the reference group (couples consisting of a Jewish woman married to a non-Jewish man) was significantly lower than the probability for all other groups, except for the single non-Jewish men, who were not significantly different from the reference group. These couples also gave significantly less to secular causes than all groups except for the non-Jewish singles, both men and women. The single Jewish 
Table 4: Regression Model of Amount Given

\begin{tabular}{l|cc|cc}
\hline \multicolumn{4}{c}{ Tobit Model: Marginal Effects } \\
\hline Dependent Variable & \multicolumn{2}{|c}{ Secular Giving } & \multicolumn{2}{c}{ Religious Giving } \\
\hline Independent Variables & $\begin{array}{c}\text { Probability of } \\
\text { Giving }\end{array}$ & $\begin{array}{c}\text { Log amount } \\
\text { conditional on } \\
\text { giving }\end{array}$ & $\begin{array}{c}\text { Probability of } \\
\text { Giving }\end{array}$ & $\begin{array}{c}\text { Log amount } \\
\text { conditional on } \\
\text { giving }\end{array}$ \\
\hline MNJW-MJM & $.120^{* * *}$ & $1.18^{* * *}$ & -0.010 & -0.045 \\
MNJW-MNJM & $.112^{* *}$ & $.519 * *$ & $.180^{* * *}$ & $.780^{* * *}$ \\
MJW-MJM & $.098^{* * *}$ & $.759^{* * *}$ & $.110^{*}$ & 0.602 \\
SJW & $.103 * * *$ & $.842^{* *}$ & 0.009 & 0.040 \\
SJM & $.133^{* * *}$ & $1.67 * * *$ & $.126^{*}$ & 0.723 \\
SNJM & 0.054 & 0.299 & 0.097 & 0.492 \\
SNJW & $.070^{*}$ & 0.381 & $.121^{*}$ & $.591 *$ \\
Pseudo R-Squared & & 0.103 & & 0.056 \\
\hline
\end{tabular}

Notes: $\mathrm{M}=$ man; $\mathrm{W}=$ woman; $\mathrm{N}=$ non; $\mathrm{J}=\mathrm{J}$ ewish; $\mathrm{S}=$ single.

The dependent variable is the logarithm of the three-year average (2000, 2002, and 2004) of giving to either secular or religious purposes. The estimates are from Tobit models. The omitted reference group is Jewish women married to non-Jewish men. The models are weighted.

Significance levels: $* \mathrm{p}<.10, * * \mathrm{p}<.05, * * * \mathrm{p}<.01$

men had the highest probability of secular giving and were about $13 \%$ more likely to give to secular causes than the couples in the reference group, while the single Jewish women were $10 \%$ more likely to do so. These data may be interpreted similarly for all the groups as compared to the reference group.

Column 2 indicates the relative amounts given by those who gave. The data show that the single Jewish men gave the most to secular causes, roughly $167 \%$ more than the reference group; the single Jewish women gave $84 \%$ more; and the intermarried couples consisting of a non-Jewish woman and a Jewish man gave $118 \%$ more. The data for the other groups may be interpreted similarly.

Columns 3 and 4 present the data for religious giving by group. Column 3 indicates that non-Jewish married couples were $18 \%$ more likely to give to religious causes than the reference group; married Jewish couples were $11 \%$ more likely to give; single Jewish men were $12.6 \%$ more likely to give; and single non-Jewish women were $12.1 \%$ more likely to give than the reference group. Column 4 shows that the non-Jewish married couples also gave $78 \%$ more than the reference group, and single non-Jewish women gave about $59 \%$ more. $^{35}$

\section{Discussion}

The extant literature on philanthropic giving indicates that single females, married men and married women are significantly more likely to be donors to charity than 
single men ${ }^{36}$ and that females are more likely to give to religious causes. ${ }^{37}$ More specifically, Piper and Schnepf found that while married men and women show the same level of support for religious organizations, single women are nearly twice as likely as single men to give to them. Even after controlling for variables like age, income, living alone, region, education and proxies for wealth, this gender difference remains significant. $^{38}$

Our study is somewhat at odds with these findings. In our sample, the single Jewish men were the most likely to give and gave more to secular causes than all the other groups, and they also gave more often to religious causes than other singles. This finding must be interpreted with more than the usual amount of caution, however, due to the small sample of single Jewish men in our data set. Thus, these results should be interpreted as suggestive of a promising topic for future study.

Our study's most surprising finding concerns married households and their different patterns of religious and secular giving. Among the intermarried Jews, giving to religious causes was predictably low compared with other groups. Additionally, if we look at the frequency distribution of the variable "attendance at religious services per year" within married households, we find that those who married within their faith reported a significantly higher frequency of religious attendance than couples who intermarried. ${ }^{39}$ Which spouse was Jewish made no difference in the frequency of religious attendance. These results are expected, in light of the standard finding that religious observance and other indicators of Jewish identification are lower among the intermarried. ${ }^{40}$

Secular giving, however, follows a very different pattern. The intermarried couples with a Jewish female spouse gave significantly less to secular causes than all other groups-singles and couples-except for the single non-Jewish men. The intermarried couples with a non-Jewish female spouse were $12 \%$ more likely to give than those with a non-Jewish male spouse; the non-Jewish married couples were $11 \%$ more likely to give; the Jewish married couples were $9.8 \%$ more likely to give; the single Jewish women were $10 \%$ more likely to give; the single Jewish men were $13 \%$ more likely to give; and the single non-Jewish women were $7 \%$ percent more likely to give.

Why were these couples-consisting of a Jewish woman who marries a non-Jewish spouse-less likely than the other groups to give to secular causes? One possible explanation is that, for American Jews, the religious/secular distinction is not clearly delineated. ${ }^{41}$ Philanthropy to Jewish causes ${ }^{42}$ or organizations such as the United Jewish Appeal, Jewish day schools and the United Jewish Federation-classified in this study as "secular" causes-may, for many Jews, fit under the rubric of religious giving. As Della Pergola has noted, "over time Jewish identification has massively drifted from religious commitment, to ethnic bond, to cultural residue, from much more to less binding and mutually exclusive valence. These changes translate into transformed individual perceptions of the meaning of Jewish collective association." ${ }^{43}$ According to Della Pergola, "a higher share of American Jews identify as an ethnic group" rather than as a religious group. ${ }^{44}$ This may lead them to assign the "religious" rubric to anything associated with their ethnic identity. 


\section{Debra Mesch, Zach Moore and Mark Ottoni-Wilhelm}

Several factors mitigate this concern for our study. First, data collection was conducted through Computer Assisted Telephone Interviewing (CATI) with each respondent, as opposed to self-administered mail-in surveys. As we have already noted, the question regarding religious giving was worded clearly to exclude giving to schools, hospitals and other charities run by religious organizations. The question regarding donations to secular causes was worded equally clearly to include categories like education, health and culture. The way these questions were posed reduced any potential misunderstanding of the survey's definition of "religious" giving versus "secular" giving. Furthermore, because an actual person asked these questions, the researchers were able to clarify any misunderstanding with the respondent during the survey process.

Second, we repeated the regression analyses examining secular giving by (1) excluding "combined-purpose" organizations such as the United Jewish Appeal, Catholic Charities, the United Way, etc.; (2) excluding "educational" and "combined purposes" giving; and (3) combining "educational" and "combined purpose" giving into one category. If the Jews in our sample had responded that "religious" giving included some of the "secular" giving categories, there would be inconsistencies in our results. Each of these analyses is discussed in turn.

For the first of these repeat analyses, excluding "combined purpose" organizations, the results were the same as in the original analysis - the intermarried couples with a Jewish female spouse were significantly less likely to give and gave significantly less to secular causes than any other group. For the second analysis, excluding both "educational" and "combined purposes" categories, the results also were the same as in the original analysis-except for the single non-Jewish women, who showed no significant difference in their secular giving from the intermarried couples with a Jewish female spouse. In the third analysis, combining "educational" and "combined purposes" giving, the results were significant only for the following groups:

- The intermarried couples with a Jewish male spouse were $15 \%$ more likely to give and gave $94 \%$ more than those with a Jewish female spouse.

- The couples in which both spouses were Jewish were $11 \%$ more likely to give than those with only a female Jewish spouse, but there was no significant difference in the amounts given.

- The single Jewish women were $16 \%$ more likely to give and gave $100 \%$ more than the intermarried couples with a Jewish female spouse.

- The single Jewish men were about $20 \%$ more likely to give and gave $140 \%$ more than the intermarried couples with a Jewish female spouse.

These results provide further support for our findings: the intermarried couples with a Jewish female spouse were significantly less likely to give and gave significantly less to secular causes than (1) the intermarried couples with a Jewish male spouse; (2) the Jews who married Jews; (3) the single Jewish women; and (4) the single Jewish men. 
These additional analyses support our original findings, and, thus, we can be more confident in our results.

Why is this happening? We know that income and education are significant predictors of giving. Examining Table 3, we see that average income, wealth and education were not consistent across the groups. From the descriptive statistics, we find that our reference group - the intermarried couples with a Jewish female spouse-had the highest mean income and wealth. However, Table 3 does not reflect the control variables used in our study. Controlling for income, wealth, education, age, number of children, age of youngest child, region, employment status and health allows us to take demographic and economic characteristics of the different sub-populations into account. Table 4 explicitly holds those demographics constant, so that differences in the demographics cannot explain the pattern we find. Inconsistently with extant research, the intermarried couples with Jewish female spouses turn out to have given less to secular causes than the other groups when we control for income and wealth in the regression.

A study by Brown and Ferris on the impact of social capital on giving and volunteering confirms the importance of social capital in explaining the generosity of individuals. As they remark, "social networks play an important role in eliciting philanthropic behavior from individuals in a community." ${ }^{45}$ One possible explanation of our result is that intermarriage changes household giving differently according to which partner is Jewish, because this affects whether the couple is tied in to Jewish fundraising networks. ${ }^{46}$ To the extent that Jewish fundraising networks in the past have been grounded in Jewish man-to-Jewish man connections, it may be that when a Jewish woman married a non-Jewish man, this weakened her linkage with these networks. If this is the explanation of our result, we would expect that the modernization of Jewish fundraising networks, so that they longer rely largely on Jewish manto-Jewish man connections, might change the picture, especially if a younger cohort of Jewish women were studied. ${ }^{47}$

Another possible interpretation is that women who are socialized to the norms and expectations of U.S. culture may be more likely to adapt to their husbands' value systems. If Jewish men have been acculturated according to the universalistic principles of tzedakah or tikkun ha'olam (rectifying the world) - important norms and values of Jewish philanthropy-the non-Jewish women they marry may take on these values and conform to the giving norms, values and social networks of their Jewish husbands. As mentioned above, Andreoni, Brown and Rischall found evidence that the giving done by married couples who make their giving decisions jointly resembles that of married couples in which the husband is the decision-maker. ${ }^{48}$ Hence, the giving patterns of Jewish women who intermarry may be conforming more to the giving patterns of non-Jewish men than to the giving patterns of other Jews. Additionally, Jewish women may self-select in marrying partners outside of their religion; their cultural connection to Jewish norms may be nominal and their Jewish social networks less extensive.

Another plausible explanation for our findings lies in the religious differences characteristic of American Jewish life-and particularly in the identifications of 
"Jewishness" likely to be given by, for example, secular, Reform, Conservative, Orthodox or ultra-Orthodox Jews. ${ }^{49}$ Extant research has pointed to the existence of "more variability in attitudes and values within Judaism than there is between Judaism and other religions." ${ }^{50}$ Consequently, the status of charity may be very different across Jewish denominations. For example, Monson found that denominational affiliation was significantly related to the types of causes to which Jews were likely to donate,$^{51}$ while Ritterband found that the Orthodox were "the most likely to give to Jewish campaigns, followed closely by the Conservatives, with the Reform adherents far behind. ${ }^{52}$

Furthermore, we know that certain factors (such as intermarried parents, lower levels of Jewish education and age) affect the probability of intermarriage, and that its incidence is not equally proportional across all Jewish denominations and nondenominational Jews..$^{53}$ Are there more secular Jewish women among the intermarried couples with Jewish female spouses? Are there other demographic differences that were not measured in our study between the non-Jewish women who marry Jewish men and those who marry non-Jewish men? Our data set did not allow us to test for these differences, although studies have shown that intermarriage does affect Jewish identity. ${ }^{54}$ For example, Phillips found that if the only Jewish parent is the father, the likelihood of Christian identification increases..$^{55}$

Of course, one must keep in mind that our sample of Jews, while representative of the proportion of Jews in the U.S. population, is nevertheless small. The first order of business in evaluating the evidence we report of low giving among intermarried couples consisting of Jewish women and non-Jewish men is to seek additional evidence from a data set that over-samples Jews. Similarly, our study examines only American Jews and cannot be generalized to Jewish communities worldwide without further data collection.

Our study is one of the few that have compared giving behavior between Jews and non-Jews by sex and type of giving. It is distinguished by its high-quality, longitudinal data set. Future research needs to further address these issues by examining additional variables that may be unique to Jewish culture-particularly the influence of social capital and denominations within the Jewish religion, and how inter-marriage affects philanthropic behavior.

Notes:

1. Gary A. Tobin, The Transition of Communal Values and Behavior in Jewish Philanthropy (San Francisco: CA: Institute for Jewish \& Community Research, 2001), p. 1.

2. Studies of the relationship between religion and giving include: I.E. Berger, "The Influence of Religion on Philanthropy in Canada, Voluntas, 17 (2006), pp. 115-132; A.C.E. Brown and J. M. Ferris, "Social Capital and Philanthropy: An Analysis of the Impact of Social Capital on Individual Giving and Volunteering," Nonprofit and Voluntary Sector Quarterly, 36 (2007), pp. 85-99; 06 Mesch philanthropy by sex.doc K.F. Forbes and E.M. Zampelli, "Religious Giving by Individuals: A Cross-Denominational Study," American

$92 \cdot$ Nashim 20 (2010) 
Journal of Economics and Sociology, 56 (1997), pp. 17-30; D.R. Hoge and F. Yang, "Determinants of Religious Giving in American Denominations: Data from Two Nationwide Surveys," Review of Religious Research, 36 (1994), pp. 123-148; J. Lunn, R. Klay and A. Douglass, "Relationships among Giving, Church Attendance, and Religious Beliefs: The Case of the Presbyterian Church (USA)," Journal for the Scientific Study of Religion, 40 (2001), pp. 765-775; D.V.A. Olson and D. Caddell, "Generous Congregations, Generous Givers: Congregational Contexts that Stimulate Individual Giving," Review of Religious Research, 36 (1994), pp.168-180; P.B. Reed and L.K. Selbee, "The Civic Core in Canada: Disproportionality in Charitable Giving, Volunteering, and Civic Participation," Nonprofit and Voluntary Sector Quarterly, 30 (2001), pp. 761-780; M.D. Regnerus, C. Smith and D. Sikkink, "Who Gives to the Poor? The Influence of Religious Tradition and Political Location on the Personal Generosity of Americans toward the Poor," Journal for the Scientific Study of Religion, 37 (1998), pp. 481-493; and P.A. Zaleski and C.E. Zech, "Economic and Attitudinal Factors in Catholic and Protestant Religious Giving," Review of Religious Research, 36 (1992), pp. 158-167.

3. See M. Chaves, "Financing American Religion," New Directions for Philanthropic Fundraising, 35 (2002), pp. 41-54; and the articles by Forbes and Zampelli; Hoge and Yang; Reed and Selbee; Zaleski and Zech; and Zaleski, Zech and Hoge cited in note 2.

4. Rene Bekkers and Pamala Wiepking, "Generosity and Philanthropy: A Literature Review," available at http://papers.ssrn.com/sol3/papers.cfm?abstract_id=1015507 (2007).

5. I.M. Sheskin and A. Dashefsky, "Jewish Population in the United States, 2008," American Jewish Year Book, 108 (New York: American Jewish Committee, 2008), pp. 151-222.

6. Gary A. Tobin and A.K. Weinberg, "Mega-gifts in Jewish Philanthropy 2001-2003" (San Francisco, CA: Institute for Jewish and Community Research, 2007), p. 1.

7. See Tobin, Transition of Communal Values (see above, note 1).

8. J.I. Lifschitz, "Welfare, Property, and Charity in Jewish Thought," Society, 44 (2007), pp. 71-78.

9. Tobin, Transition of Communal Values (above, note 1), p. 1.

10. C. Kadushin, and L. Kotler-Berkowitz, "Informal Social Networks and Formal Organizational Memberships among American Jews: Findings from the National Jewish Population Survey 2000-01," Sociology of Religion, 67 (2006), pp. 465-485.

11. M. Rimor and Gary A. Tobin, "The Relationship Between Jewish Identity and Philanthropy," in B.A. Kosmin and P. Ritterband (eds.), Contemporary Jewish Philanthropy in America (Savage, MD: Rowman \& Littlefield, 1991), pp. 33-36.

12. Tobin, Transition of Communal Values (above, note 1), p. 2.

13. E.g., James Andreoni, Eleanor Brown and Isaac Rischall, "Charitable Giving by Married Couples: Who Decides and Why Does It Matter?" Journal of Human Resources, 38 (2003), pp. 111-133; C.B. Burgoyne, B. Young and C.M. Walker, "Deciding to Give to Charity: A Focus Group Study in the Context of the Household Economy," Journal of Community \& Applied Social Psychology, $15 / 5$ (2005), pp. 383-405; Patrick M. Rooney, Eleanor Brown and Debra Mesch, "Who Decides in Giving to Education? A Study of Charitable Giving by Married Couples," International Journal of Educational Advancement, 7 (2007), pp. 229-242; Pamela Weipking and Rene Bekkers, "Does Who Decides Really Matter? Causes and Consequences of Personal Financial Management in the Case of Larger and Structural Charitable Donations," Voluntas, 21 (2010), pp. 240-263, and B.K. Yoruk, "Charitable Giving by Married Couples Revisited," Journal of Human Resources, 45 (2010), pp. 497-516. 
14. Berger, "Influence of Religion on Philanthropy" (above, note 2), p. 126.

15. Mark Ottoni-Wilhelm, "Giving to Organizations that Help People in Need: Differences across Denominational Identities," Journal for the Scientific Study of Religion, 49 (2010), pp. 389-412.

16. Lifschitz, "Welfare, Property, and Charity in Jewish Thought" (above, note 8), p. 71.

17. National Jewish Population Survey 2000-01: Strength, Challenge and Diversity in the American Jewish Population (New York: United Jewish Communities, 2003), p. 14.

18. Kadushin and Kotler-Berkowitz, "Informal Social Networks" (above, note 10).

19. Tobin, Transition of Communal Values (above, note 1), p. 24.

20. M. Tress and Barry S. Kosmin, "Tradition and Transition in Jewish Women's Philanthropy," in Kosmin and Ritterband, Contemporary Jewish Philanthropy (above, note 11), p. 77.

21. L. Kamas, A. Preston and S. Baum, "Altruism in Individual and Joint-Giving Decisions: What's Gender Got to Do with It?" Feminist Economics, 14 (2008), pp. 23-50; and Rooney, Brown and Mesch, "Who Decides" (above, note 13).

22. Schneider, "Jewish Women's Philanthropy," Lilith, 18 (1993), p. 12.

23. S. Andron, "Public vs. Private Jewish Philanthropy: The Role of the Professional in an Era of Change," Journal of Jewish Commual Service, 83 (2008), pp. 140-145.

24. E.g., Andreoni, Brown and Rischall, "Charitable Giving by Married Couples" (above, note 13); Rene Bekkers, "Giving and Volunteering in the Netherlands: Social and Psychological Perspectives" (Ph.D. Dissertation, University of Utrecht ,2004); K.G. Carman, "Social Influences and the Private Provision of Public Goods: Evidence from Charitable Contributions in the Workplace" (Discussion Paper, Stanford Institute for Economic Policy Research, 2006); R. Croson and N. Buchan, "Gender and Culture: International Experimental Evidence from Trust Games," American Economic Review, 89 (1999), pp. 386-391; C. Eckel and P.J. Grossman, "Are Women Less Selfish than Men? Evidence from Dictator Experiments," Economic Journal, 108 (1998), pp. 726-735; C. Eckel and P.J. Grossman, "Chivalry and Solidarity in Ultimatum Games," Economic Inquiry, 39 (2001), pp. 171-187; eidem, "Rebate versus Matching: Does How We Subsidize Charitable Contributions Matter?" Journal of Public Economics, 87 (2003), pp. 681-701; C. Eckel, P.J. Grossman and R.M. Johnston, "An Experimental Test of the Crowding Out Hypothesis," Journal of Public Economics, 89 (2005), pp. 1543-1560; Kamas, Preston and Baum, "Altruism" (above, note 21); Debra Mesch et al.,"The Effects of Race, Gender, and Marital Status on Giving and Volunteering in Indiana," Nonprofit and Voluntary Sector Quarterly, 35 (2006), pp. 565-587; and P. Rooney et al., "The Effects of Race, Gender, and Survey Methodologies on Giving in the U.S.," Economics Letters, 86 (2005), pp. 173-180.

25. James Andreoni and Lise Vesterlund, "Which is the Fair Sex? Gender Differences in Altruism," Quarterly Journal of Economics, 116/1 (2001), pp. 293-312.

26. J.D. Cox and C.A. Deck, "When Are Women More Generous than Men?" Economic Inquiry, 44/4 (2006), pp. 587-598.

27. Kamas, Preston, and Baum, "Altruism" (above, note 21), p. 34.

28. Mesch, "Effects of Race" (above, note 24); Rooney, "Effects of Race" (above, note 24).

29. G. Piper and S.V. Schnepf, "Gender Differences in Charitable Giving in Great Britain," Voluntas, 19 (2008), pp. 103-124.

30. Andreoni, Brown, and Rischall, "Charitable Giving by Married Couples" (above, note 13), p. 127.

31. Yoruk, "Charitable Giving by Married Couples Revisited" (above, note 13).

94 • Nashim 20 (2010) 
32. Mark Wilhelm, "New Data on Charitable Giving in the PSID," Economics Letters, 92 (2006), pp. 26-31; and idem, "The Quality and Comparability of Survey Data on Charitable Giving," Nonprofit and Voluntary Sector Quarterly, 36 (2007), pp. 65-84.

33. All twelve single Jewish men responded with the exact amounts that they gave to both religious and secular causes. This analysis revealed one large outlier in the religious giving data, a man who gave $\$ 60,412$. We conducted the regression analyses with and without this outlier, and the main results remained basically unchanged.

34. We also ran these regressions using a log-log model for income rather than the dollar amount, but this did not change the results.

35. Comparisons between groups: Because the analysis used the intermarried couples consisting of a non-Jewish man and a Jewish woman as the reference group, the data in Table 4 indicate the relationship and significance between this group and each of the independent variables (i.e., the other groups). This table does not reveal the statistical significance among the other groups. However, by subtracting the probability of giving between two groups, we can determine the relative difference in their likelihood of giving. For example, to compare the probability of secular giving between the single Jewish women and the single Jewish men, we subtract .103 from .133; thus, the probability of giving for the single Jewish men was approximately $3 \%$ more than for the single Jewish women. By a similar calculation, we find that the single Jewish men were $6 \%$ more likely to give than the single non-Jewish women. The same calculations may be carried out for the amounts given. Again, for secular giving, the single Jewish men give $91 \%$ more than the couples in which both spouses were Jewish and 83\% more than the single Jewish women.

36. See Kamas, Preston and Baum, "Altruism" (above, note 21); Mesch et al., "Effects of Race" (above, note 24); Piper and Schnepf, "Gender Differences in Charitable Giving" (above, note 29); and Rooney et al., "Who Decides" (above, note 13).

37. See R.H. Newman, "Perception of Factors Relating to Gender Differences in Philanthropy" (Ph.D. Dissertation, University of San Francisco, 1995); Piper and Schnepf, "Gender Differences in Charitable Giving" (above, note 29); and S.T. Yen, "An Econometric Analysis of Household Donations in the USA," Applied Economic Letters, 9 (2002), pp. 837-841.

38. Piper and Schnepf, "Gender Differences in Charitable Giving" (above, note 29), p. 114.

39. Frequency of religious attendance was not included as a control variable in the regression analysis.

40. National Jewish Population Survey (above, note 17).

41. S. Della Pergola, "New Data on Demography and Identification among Jews in the U.S.: Trends, Inconsistencies, and Disagreements," Contemporary Jewry, 12 (1991), pp. 98-116.

42. Barry Kosmin, "The Dimensions of Contemporary American Jewish Philanthropy," in Kosmin and Ritterband, Contemporary Jewish Philanthropy (above, note 11), pp. 17-30.

43. Della Pergola, "Thoughts of a Jewish Demographer in the Year 2000," Contemporary Jewry, 21 (2000), p. 110.

44. Idem, "New Data" (above, note 41), p. 77.

45. Brown and Ferris, "Social Capital and Philanthropy" (above, note 2), p. 86.

46. Other studies have revealed the importance of social connections and networks within Judaism. See D.W. Hurst and F.L. Mott, "Secular Pay-Offs to Religious Origins: Gender Differences among American Jews," Sociology of Religion, 67 (2006), pp. 439-463; R.G. Monson, "Patterns of Giving of Some Jewish Career Women: A Preliminary Investigation," in Kosmin and Ritterband, Contemporary Jewish Philanthropy (above, note 11), 


\section{Debra Mesch, Zach Moore and Mark Ottoni-Wilhelm}

pp. 117-131; and B.T. Philips and S.B. Fishman, "Ethnic Capital and Intermarriage: A Case Study of American Jews," Sociology of Religion, 67 (2006), pp. 487-505.

47. The authors thank Shoshanna Ratzabi for this insightful suggestion.

48. Andreoni, Brown, and Rischall, "Charitable Giving by Married Couples" (above, note 13).

49. Della Pergola, "New Data" (above, note 41).

50. Hurst and Mott, "Secular Pay-Offs to Religious Origins" (above, note 46), p. 441.

51. Monson, "Patterns of Giving of Some Jewish Career Women" (above, note 46).

52. P. Ritterband, "The Determinants of Jewish Charitable Giving in the Last Part of the Twentieth Century," in Kosmin and Ritterband, Contemporary Jewish Philanthropy (above, note 11), pp. 57-72.

53. Della Pergola, "New Data" (above, note 41); National Jewish Population Survey (above, note 17$)$.

54. See B. Farber and L. Gordon, "Accounting for Jewish Intermarriage: An Assessment of National and Community Studies," Contemporary Jewry, 6 (1982), pp. 47-75; B. Phillips, "Assimilation, Transformation, and the Long Range Impact of Intermarriage," Contemporary Jewry, 25 (2005), pp. 50-84; L.J. Warte and J.S. Friedman, "The Impact of Religious Upbringing and Marriage Markets on Jewish Intermarriage," Contemporary Jewry, 18 (1997), pp. 1-23; and W.P. Zenner, "Jewish/Gentile Intermarriage: An Interpretation," Contemporary Jewry, 12 (1991), pp. 35-43.

55. Phillips, "Assimilation, Transformation" (above, note 54). 
Copyright of Nashim: A Journal of Jewish Women's Studies \& Gender Issues is the property of Indiana University Press and its content may not be copied or emailed to multiple sites or posted to a listserv without the copyright holder's express written permission. However, users may print, download, or email articles for individual use. 